\title{
UMMAH IMAGINATIONS IN PLURAL KERALA: Being International in the Traditional Way
}

\author{
Mamdooh Abdul Fathah \\ Jamia Madeenathunnoor, Calicut, Kerala \\ Email: abdulfathahuniversity@gmail.com
}

\begin{abstract}
Quranic 'Ummah' with its political and social sensibilities in a period of authoritatively heterogenetic counter-resurgences is significant for Muslims constituting minority in Kerala, India. However, 'Ummah' as an euphemism for state-centered political aspirations become endemic to them only in the last century. This tendency could be linked to literal scriptural interpretations, contempt for the technocratic and mystic traditions and the idea of sacredgeographies pushed inward by reformist movements since 1920s, which disjuncts with classical hermeneutic traditions followed by Keralite Ulama by their distinctive longue-durée to mainstream Muslims lands. Recently through a revivalist campaign, the traditional Ulama refurnished their monolithic concept of Ummah by reimagining and re-appropriating those sacred imaginaries from the puritanicalIslamist claim of the pure. An embedded Ummah locality - a mixture of local products and global variants - thus piggybacked on the structural and cultural forces of globalization, allowing Ulama to prudently redraw the boundaries of national culture and its ally, local Islam. Through this paper, I try to explicate how traditional Muslim scholarship in Kerala employed Quranic Ummah in the plural society while structurally re-embedding it with the global Muslim whole. A short reflection on the interpretive paradigm of puritanical-Islamist orientations on the concept of Ummah will be given along to place various paradigms in a comparative framework.
\end{abstract}

Keywords: Quranic 'Ummah', Traditional Ulama, Reformist Islam, Keralite Islam, Islamicate Global Imaginations, Globalization, Pious Neoliberalism

DOI: https://doi.org/10.20414/ujis.v25i2.456

\section{Introduction}

THE TERM Ummah carries due significance for Muslims as it appears sixty-four times in the holy text, of which the plural Umam has been employed in thirteen instances. Forty-one of these 
occurrences are in Mecca while the rest, thirteen, are Medinan verses. As a broad term, the Ummah lends itself to distinct realities and shades of meaning. In general, it could be concluded as body of people who are objects of divine plan of salvation. Moving from Meccan to Medinan verses discern a gradual change in reference to the term. In the Meccan instances, the term envisages distinct features of communities or national in general. In the last stages of this era, the term has been attributed more to religious communities preached by prophets as to the original religious communities of the whole mankind. In the Medinan verses, the term is now exclusively used to mean religious community. In the last instances, it has been used to mean religious community, but in the sense of each particular group or religious tradition or some section of them. Of these variants, it is the Ummah of Muhammad PBUH which is bestowed with the title of "moderate community" (Al-Baqara 2:143) "the best community" (Ali Imran 3:110) with the task of inviting others to that which is good (Ali Imran 3:104) and of vying with others in good works (Al-Ma'ida 5:48). These designations thus pencils Ummah Muhammad as the standard bearer of Ummah in the prophetic tradition and has made the term a sole property of Ummah Muhammad as an historical continuation. Ummah Muhammad, in its technical and legal reality embraced only Muslims and thus is a single Ummah rather than a composite Ummah as a couple of western scholars such as Montgomery Watt seems to espouse.

The question that I address, therefore, is how traditional Muslim scholars of Kerala where Muslims dwell as minorities, with its plural cultural matrix and still dynamic reciprocities with foreign lands, profoundly conceive and employ concept of Prophetic Ummah in the entirety of its textual and historical variants across time and space. This is interesting considering that it is the hermeneutically varied and conflicting shades of the same concept that each of the factions vying for the legitimacy of their respective understanding of Ummah make use in the discursive field of Keralite Muslim public. Further, the spatial and ethnic setting of this study is warranted in the sense that this region inhabits a peculiar cultural geography with regard to maritime and migratory connections with wider Islamicate and Arab world 
and traditional Ulama-led Islamic revivalism piggybacked on structural and cultural forces of globalization. Tracing the spatiotemporal reproductions and manipulations of a religiously and politically saturated concept as the Ummah will further contribute to understanding the embodied forms of the Quranic textual universe. The historical and theological origins of this revivalism will also help understand why similar attempts to globalize Keralite Islam from reformist side through the narratives of 'true Islam' misplaced the boundaries of legal-theological divisions, failed to negotiate with organic religious-political structures to legitimize their 'pure imaginations' and consequently succumbed to disintegration and political rejection of their purity norms. While the same could be said for fellow Islamicate lands in the Indian Ocean rim, Kerala's cosmopolitan disposition and its simultaneous points of convergence and divergence from subcontinent's Muslim history and narratives lends an environment enough to place various ideological and organizational perceptions about Quranic Ummah in a pluralist political sphere. While this work certainly brings forth the social and political leverage of traditional trajectory, they are not always paradigmatic as questions still pervade the religiousness of neoliberal forces penetrating the volatile notions of the sacred and the welfare in this process, among others.

Before plunging into the world of Muslim discourses in Kerala, I find it equally significant to provide a short retrospection on the Keralite Islam to provide more clarity and reference point for further contextualization this study demands. Prange's work ${ }^{1}$ is insightful to state here that spread of Islam in Kerala, situated at the far end of southern India, bordering Indian Ocean, is indebted more than elsewhere to merchant and wandering-saint classes than political entities. Consequently, presence of Islam in this Malayalam-speaking state can be established from a relatively earlier period than the rest of Indian subcontinent i.e., the first

1 See Sebastian R. Prange, Monsoon Islam: Trade and Faith on the Medieval Malabar Coast, Cambridge Oceanic Histories (Cambridge: Cambridge University Press, 2018). 
century Hijri, with certain popular legends in the region going back as far as Prophets' time in Medina. The distinct oceanic and mercantile nature of Keralite Islam means that, as different from mainland Indian Islam, the proselytization missions of Arabs from Hadramawt, Cairo and even Hijaz region in the Indian ocean littoral, specifically the ancient Keralite ports of Muziris and Calicut made much impact on their religious landscape and discursive culture. The overwhelming prevalence of Shafii-school of jurisprudence, Sufi-Sunni Islam, Asharite theology and embodied rituals among them goes back genealogically to the religious repertoire of these saintly preachers, making them much more identical to Muslims from other Indian ocean littorals where Hadhrami saints have anchored like Malay Archipelago, southern India, the Red Sea, and East Africa. The parameters of this particular Islam underwent massive changes and a new factional metric was introduced into the Keralite Islam following the wider reformist trend of Egyptian reformists and circulation of these ideas among the educated and ruling elites of Kerala during 1920s, however few they are. The reformist stance triggered by those like Vakkam Moulavi, a newspaper proprietor and freedom fighter in his own right, and later through Nadwat-al-Mujahideen argued for a more scriptural Islam that downplayed the discursive field of juridical schools and began to negate the embodied particulars of saintly rituals. As I have argued elsewhere, ${ }^{2}$ long before Salafibism as a synchronistic orientation received worldwide attention in 1970s, reformist trajectory in Kerala is peculiar to have exhibited universalistic reformist narratives of both Saudi Wahabism and Egyptian Salafism, not to mention the social, political and historical baggage of wider twentieth century reforms in Kerala. The consolidation of the category of 'reformism' vis-e-vis 'traditionalism' that had for long warranted religious and tactical responses from native Ulama in the region owe their origin to this

${ }^{2}$ M Abdul Fathah, "Terrorism, an Orphan of Reformist Islam: Reflections from Kerala Muslim Milieu," WordPress.com, Cafe Dissensus Everyday, May 11, 2018, accessed November 23, 2021, https://cafedissensusblog.com/2018/05/11/terrorism-an-orphan-of-reformistislam-reflections-from-kerala-muslim-milieu/. 
distinct historical phase. These categories have since then engineered the frameworks of factional exchanges, ideological debates and had bearing upon further categorizations. The term 'Sunni', for instance, is usually used as an 'other' of reformist Islam which includes local Mujahid (named after Nadvat-ulMujahideen) and Islamist factions (namely Jama'at-e-Islami) and is equated with traditional Islam, unlike the global variant that is more often used vis-e-vis the Shia denomination. Scholars often compare Sunnis and Mujahids to Barelwis and Ahl al-Hadith in the Northern India respectively. ${ }^{3}$ Accordingly, the 1920s' moment in Kerala draw parallels with Barelwi revival of traditionalism in response to Deobandi and Ahl al-Hadith threats in early Twentieth century Uttar Pradesh. These comparisons, however, should only be used for gauging the historical place of traditional Islam in Kerala as the factional metric and ideological lines of respective organization from both ends of the subcontinent does not always run parallel.

The other issue that needs addressing before broaching the interpretative paradigm of traditional scholars is, unsurprisingly, the question of who constitute the traditionalists and what plausibly can be the essence of traditionalism in this context. Being traditional or being a traditionalist amounts to a highly controversial debate that surround around questions of authority, continuity and a number of jurisprudential and theological issues related to Isnād, Madhhab, Thaqlìd and Ușül. My understanding of Traditional in this context is akin to S.N. Eisenstadt's use of the term that is best summarized as an attempt to consider "certain parts of the older generation as the legitimate symbols of traditional order" and upholds them as part of their ideological stance against newer and 'modernist' trends. ${ }^{4}$ As I would elaborate later in the paper, traditionalists here are certainly not anti-modern or neo-Luddites for that matter. The Sunni Ulama in Kerala, who I call the traditional scholars, vis-e-vis reformists, emphasize

${ }^{3}$ Y. Sikand, Bastions of the Believers: Madrasas and Islamic Education in India (Delhi: Penguin, 2005).

4 S. N. Eisenstadt, "Post-Traditional Societies and the Continuity and Reconstruction of Tradition," Daedalus 102, no. 1 (1973): 22. 
adherence to four Sunni schools of law, believes in the legitimacy of Ash'ari and Maturidi schools of theology, practices Shariadriven Sufism and consider themselves as faithful bearers of classical Sunni tradition. However importantly, this does not consider these categories as certain essential set of ideas produced in isolation nor a normatively void categorization, rather the consolidation of these unstable categories owes themselves to the discursive field of Keralite Islam and the dynamic nature of dialogue, practice and narratives espoused by each faction vis-evis the other. Recently, neo-traditionalism is pervasively used to denote similar revival of traditional scholars world-wide. While they certainly benefit approaching the issue from a cosmopolitan vantage point and bring much more linearity to the Umma-istic framework, I have chosen not to entertain the term as it brings along certain notions of departure from the Classical tradition and a homogenous and vertical narrative that discards local orientations and improvisations.

In the first part of this paper, I would demarcate interpretive paradigm of radical Islamists and classical interpretations on Ummah and show how the later successfully manifest in present hermeneutical context through traditional Ulama. In the Second section, I would then contemplate the latter's application among Kerala Muslims and the larger pluralist environment around them in a chronological order

I will attend to this debate from a framework that M.S. Visakh et al has recently articulated by the concept 'true Islamicate-global imaginations'. ${ }^{5}$ Looking at the research subject through the prism of carefully filtered negotiations between localized identities and transnational Muslim imaginations helps the author to transverse the conventional national-local or even static global identity scales of Keralite Islam and simultaneously place their formation within the open-end theoretical frameworks of late modernity. This work follows a combination of ethnographic and historical analyses to broach these nuances. Archives, magazines and other historical

5 M. S. Visakh, R. Santhosh, and C. K. Mohammed Roshan, "Islamic Traditionalism in a Globalizing World: Sunni Muslim Identity in Kerala, South India," Modern Asian Studies 55, no. 6 (November 2021): 7. 
documents detailing the formation and ideological-organizational fissures in Keralite Islam has greatly aided this project. Further, a pluralistic approach is used for the study of Islamic legal history and Quranic Tafseer/hermeneutics by blending traditional historical approaches with methods of qualitative analysis. Pluralistic methodologies bring together capabilities of multiple disciplinary methods in a coherent framework and is necessary to tackle the complexity and contextuality of various research questions around concept of Ummah in Quran that further intersect with debates surrounding other disciplines.

\section{Post-colonial politics of True Islam}

Post-colonial period in the Muslim world had witnessed excessive politicization of the term Ummah from radical Muslim intelligentsia. These interpretations are rooted in the belief that Islam has been displaced from its position of influence in human affairs and that it must strive to retain this power. In their interpretative paradigm of the verses 3:10 and 3:104, Maududi and Sayed Qutub showcases Ummah as one for the leadership and guidance of human kind without which Ummah would not find its true existence as "wasat" and "best". For Maududi, Ummah prerequisites global political leadership and thus he bestows modern political ideologies with stigma of paganism. For Qutub, Ummah exist for power and thus he had emphasized that the God alone is sovereign and men specifically and Ummah as a whole should not submit to other creatures or concepts. ${ }^{6}$ Such an act would end up in "servitude of servants" and takes away from the God his sovereignty on earth. He contended that Muslim should bequeath political and legislative needs from Quran.

As there's only one God, there should be only one community of believers - no social, class, tribal, national, regional, racial, ethnic or gender differences within community. ${ }^{7}$ Fidelity to a nation state is considered inconsistent with concept of Ummah and

\footnotetext{
${ }^{6}$ G. C. Decasa, The Quranic Concept of Ummah and Its Function in Philippine Muslim Society (Roma: Gregorian Biblical Book Shop, 1999), 301-305.

${ }^{7}$ Sabila Kadiruzzaman, Islam Without Borders: Transnationalism, Social Justice, and Refugee Assistance (Notre Dame: The Program on Law \& Human Development, University of Notre Dame, 2012), 12.
} 
resembles with the practice of shirk during Idolatry. ${ }^{8}$ Qutub further discerns that demarcation between Dār al-Islām and Dār al-Harb topples any chance for Muslim Ummah to peacefully inhabit with non-Muslim in a nation state. His perceived relationships between these two states are off frequent skirmishes and struggle. However, it seems that such demarcations were long before drawn by traditional Ulama to differentiate the applicability of certain Islamic laws between these lands. They never had any intention to dictate the eternal and intuitive relationships between these lands. Moreover, Islam has a comprehensive and tolerable approach in dictating Muslim contact with non-Muslims. ${ }^{9}$

More modernist figures in the Salafiyya movement such as Muhammed Abduh had a much more apologetic stance in arguing that the internal rejuvenation of Ummah required a renewed and rational understanding of scriptures, a break from what he called the rigid structures of scholastic theology and technocratic tradition of Taqlid. His deep-seated commitment to western liberalist ideas of humanism meant that he exhorted each member of Ummah to realize their capacity as free agents of action and thought through Ijtihad. As Ebrahim Moosa ${ }^{10}$ has noted perceptively, in their attempt to find answer to loss of Islam as a leading principle of guidance and subservient role of Muslim Ummah in the global scenario, these modernists benefited in a great deal from western ideas of rationality and modernizing structures of state. This break is marked by Muhammed Abduh's argument that constitutional institutions of modern world are identical to the Shura of canonical Islam and that Muslim Ummah ought to rally behind them, a radical change from earlier reformist figures like Tahtawi who simply argued lack of conflict between two ideals. Nevertheless, their pioneering shift in the role of Ummah and the new notions of social engineering they have espoused- "from the idea of divine voluntarism to that of human

${ }^{8}$ Sayyīd Quṭb, F̄̄ Zilāl al-Qur'ān (Cairo, Egypt: Dār al-Shurūq, 1988), 1413/3.

${ }^{9}$ Usama al-Sayyid, al-Haqq al-Mubīn fì Raddi 'ala Man Talā'aba bi al-Dīn, trans. Arafa Waleed (Abu Dhabi: Dār al-Faqīh, 2017), 69.

${ }^{10}$ Ebrahim Moosa, "The Debts and Burdens of Critical Islam," in Progressive Muslims: On Justice, Gender and Pluralism, ed. Omid Safi (Oxford: Oneworld, 2003), 111-127. 
voluntarism" 11are often pointed out for the failure of their generation to find a middle ground for the pressing politicoreligious questions of the time.

While Qutub's and Mawdudi's hermeneutical stances are more directly subscribed by certain Islamist-reformist networks in the state, modernist inputs don't have a clear heir despite that their influence is spread across the time and space of Keralite reformism. The modernist reformism of Abduh and his disciple Rashid Rida had kickstarted the wave of 1920s Islamic reformism in the state through the pages of Al Manar, a magazine to which many founding fathers of the current Mujahid factions have subscribed. Nevertheless, Mark Sedgwick in his pioneering work on Muhammed Abduh was right to note that despite being the forerunners of various reformist factions that would emerge in the decolonized world, their age was "an age that was soon to pass"12 and their influence in the Islamic world had almost completely faded by 1950s. In a similar fashion, the names of Ibn Taymiyya, Muhammed Ibn Abdul Wahab and other Saudi Arabian scholars now dominates the ideological and historical narratives of contemporary Mujahid factions and their influence had far outclassed its Egyptian modernist roots. This might have to do with the Modernist scholars losing out to Salafi-Islamist and then traditionalist scholars at global stage and their attempt to pave out a leveraging position vis-e-vis Saudi Arabia and other gulf states with which Kerala have an ennobling migration culture. This doesn't mean that their organizational and ideological tension has settled in favour of one party as fissures continue to plague the Mujahid factions with groups alleging disproportionate sway of Saudi-Arabian Salafism and Modernist ideologies over others.

However, Modernists' largely material conception about Ummah's place in the modern world and enlightenment notions of historical progress sat well with Salafi contempt for the technocratic, mystical traditions and methodological precedents of

11 Malcolm H. Kerr, Islamic Reform: The Political and Legal Theories of Muhammad Abduh and Rashid Rida (California: University of California Press, 1966), 223.

${ }^{12}$ Mark Sedgwick, Muhammad Abduh (Oxford: Oneworld, 2009), 128. 
Sunni Islam with which Keralite reformists to this period identified, even though modernists themselves would fail by the standards of Qutub and Maududi's politicization of the term or the puritanic conception of the Salafis arguing for a 'decultured' Ummah free of any innovations in thought and action. It is worth noting here that even Qutub and Maududi owe their radical Islamist interpretations to this watershed moment in reformist historiography kickstarted by these modernists i.e, Islam's transformation into an object of ideological conflict in the face of modern epistemic and statist framework and the subsequent fading of the boundaries between permissible and impermissible realms of human knowledge creation. The Islamist interpretation that emerged to occupy this space found answers in, Sherif Younis' words, "building an authoritarian vision of the religion that was based on state's subordination to a global conception of Islam i.e. on the integral islamization of the same modern state". ${ }^{13}$ More specific catalysts for their interpretations could in fact also be traced back to their contempt for how British colonial projects and western secular models have deeply destabilized and desensitized the traditional Islamic structures and scholastic dynamism in British India and Socialist Egypt.

Wholly, in the Keralite context, the modernist deconstruction of the scholastic authority had empowered any one among the Ummah, sometimes without required qualifications as enshrined in classical texts, to return to literal and often dangerous interpretation to suit personal advantage. This along with calls for "deculturation" and the Takfiri tendencies of post-colonial radical interpretations have both discredited the religious and political leverage of reformists in a pluralist environment and their acceptance as legitimate parties in the $20^{\text {th }}$ century reformist wave across the state.

13 Sherif Younis, "How 'Abduh's Caftan Brought Forth Today's Islamic Ideologies," Fondazione Internazionale OASIS, last modified July 31, 2015, accessed January 23, 2021, http://www.oasiscenter.eu/en/how-abduhs-caftan-broughtforth-todays-islamic-ideologies. 


\section{Classical interpretations and the traditional command structures}

There is considerable disjunction between these radical constructions and classical interpretations of the term Ummah. As regarding the question why the Ummah Muhammad is the best community, Al Tabari stressed the opinion that "god brought forth the Muslim community as the best" as the most prominent. ${ }^{14}$ This starkly contrasts with the former's argument regarding nonexistence of the Ummah if it ever failed to preserve its duties i.e. in the absence of political leadership of the globe. Moreover, in classical interpretative paradigm of the term, the underlying themes for existence of Ummah has been outlined as spiritual reality, rather than going for any introspection for any typical political apparatus as a perquisite for Ummah. Nevertheless, medieval Muslim Scholars have emphasized Other ReligioCommunal concepts along with Ummah in accordance with their contemporary political situations. Ibn Khaldun profoundly conceives the imperative of political apparatus for Ummah, whereas Imam Gazzali rationalized Khiläfah (in his diction, sultan) for the unity of Ummah. ${ }^{15}$ This shows that the term is to be applied to the present historical situation rather than a restoration of its foundational historical contextualization, thus giving it a transhistorical and trans-geographical hue. This dimension of Islamic nation which give a whole capacity as regard s to time and space allude that the absence of caliphate will only weaken it, without completely dismantling its edifice.

As a whole, belonging to several identities never make one cease to be a member of Ummah, bringing together itself a multiplicity of nations and tribes, as long as Islam guide Ummah and govern its action. Almighty says: "And made you into peoples and tribes, so that you might come to know each other. The noblest of you in Allah's sight is the one who fears him most. Allah is all knowing and all aware". ${ }^{16}$ Furthermore, Imam Razi's

${ }^{14}$ Abū Ja'far Muhammad ibn Jarīr ibn Yazīd al-Ṭabarī, Jāmi' al-Bayān fì Ta'wōl al-Qur'ān (Beirut: Dār al-Fikr, 2001), 9-24.

${ }^{15}$ Necmettin Gökkır, "Political Language of Tafsir: Redefining of Ummah, A Religio-Communal Concept of the Quran: Past and Present," İstanbul Üniversitesi Illahiyat Fakültesi Dergisi 15 (January 1, 2007): 262.

${ }^{16}$ Al-Hujurāt 49: 13 
hermeneutic proofs for patriotism and fidelity towards once motherland is worth mentioning. In his interpretation of the verse 3:44, He says: "Cutting loose from one's own region is being equated with suicide. This shows that links with motherland and love for the same are instincts formed deep inside the soul" ${ }^{17}$ Mulla Ali Al Qari, while contemplating on why interpretations have given "being expelled from motherland" as a possible meaning for "Fitnah" appearing in the verse "Fitnah is worse than killing" (2:191), says further: "Being removed from our familiar motherland is the greatest calamity". ${ }^{18}$

The historical and circumstantial reasons as to why an overwhelming number of classical Sunni Ulama would interpret this concept with a more spiritual and theosophical insight as such and not in a politically saturated way as the radical intelligentsia of post-colonial world had done is not surprising. These scholars lived during a relatively prosperous period in Islamic history when the classical Islamic social corporates such as the Ulamaspiritual structures and political formations had more or less remained static or had changed through internal dynamics. The Islamic episteme has been continuing as domineering and authoritative without significant and radical ruptures forced from outside. These circumstantial reasons however fail to provide the complete picture since the classical interpretations of Ummah have more or less remained the same without significant deviations even after political ruptures happened as a result of Mongol expansion and crusades. The cornerstone of this trajectory thus lies in the carefully preserved scholastic clusters, Madhab networks and the notions of Taqlid that spliced those writers into a single whole representing the classical hermeneutical tradition. The writers themselves were ascetics whose memberships in various spiritual guides overlapped with their own role as legal and hermeneutic scholars and in times when they are aligned to a political or social corporates, the textual universe of the scholastic

${ }^{17}$ Fakhr al-Dīn al-Rāzī, Tafsīr al-Kabīr (Beirut: Dār al-Ḥayā al-Turath al-Azali, 1995), 130.

18 Mulla 'Ali ibn Sultan Muhammad al-Qari, Mirqat Al-Mafatih, vol. 6 (Islamic Library App., 1992), 2630. 
estate hardly allows them to radically differ from its methodologies.

In the classical concept of Ummah, existence of Muslim Ummah is solely founded on the twin principles of divine unity and Muhammadan reality. Thus, the nation becomes depository of Muhammadan message i.e. the Quran. There are theological and legal nuances other than the psychological and social complex that drives this classical Sunni position completely different from Taymiyyan-influenced reformist vision and how they are manifested in public. Reformists has a cosmogenic understanding of Ummah as the subset of individual Muslims residing in the world today whose position as a 'direct-access society' mediated by God's will is drawn on a severely limited fitri pre-temporal covenant with God prior to prophetic mission. Sunni conceptions however introduces Muhammadan apostleship to this tripartite definition as a this-worldly rope ( $h a b l)$ relating unconditional meanings of God's law to its transcendent manifestation and thus overcoming the dilemma of justice deferred in the divine command theory. This attest an immanent trans-historical and trans-geographical nature to Ummah that extends to include the present and absent realities i.e., not the mortal individuals, but the communal social structures timelessly and organically reproduced elsewhere, and whose leadership is vied by Ulama class through the prophetic investiture similarly inherited.

The root of this divergence lies in Salafi contempt of Sunni prophetology that give excessive power to prophet in the heavenly command structure and considers prophet and his sovereignty still alive. The Ummah in traditional terms thus constructs political, economic, cultural and social syllable through this command structure inhabited by scholastic tradition, whose legitimacy allows them to negotiate religious systems and norms for specific time and place. In his book "Al Haqqul Mubeen" Dr. Usama Zaid Al Azhari dwells on how such a system is produced contrary to motives of many transnational terrorist outlets. He perquisites that religion should be instilled on souls before they are encoded in written constitutions and exemplifies this with the failed attempts of Islamization of many countries namely, Afghanistan, Somalia, Sudan and Iran etc. In this process, the cardinal task of integrating 
Ummah on social, cultural and economic mosaic as the cornerstone of political integration and with no coercive force is assigned upon religious scholars. ${ }^{19}$ The pre-eminence of Ulama as a selfdetermined group of people enjoying autonomous existence and agency outside the powers of state and polity in fact is a classical scholastic platitude justified and consolidated through such tropes as "the scholars are successors of the prophets". While delineating the transcendent Ulama agency and thus its politically transcategorial manifestation, others like Dr. Mona Abdul Fadl had also hinged on the reason that prophet (s) embarked upon to establish the Ummah even before the state or the sovereignty that will politically institutionally embody this nation is built. ${ }^{20}$

The reason Keralite Ulama have chosen to embark on classical notions of Ummah concept amounts to both ideological and historical undercurrents. Their distinctive longue-duree to mainstream Muslims lands from the first century Hijri have brough out a scholastic culture deeply entwined with the $15^{\text {th }}$ and $16^{\text {th }}$ century Hijazi and Cairene descendants of Classical masters of Islamic Law. Qurrah al-ayn and Fath al-mu'inn, which are historically considered to be the earliest comprehensive legal texts in the Kerala realm trace their genealogy to the intellectual spectrum and Shafiite networks of classical Islam. Moreover, the scholastic culture of Keralite Islam had been cemented by the $19^{\text {th }}$ century that further ideological exports from the reformist clusters in Arab world since then were more or less summarily rejected in favor of continuity and authority. The factional metric of Keralite Islam worked in ways that helped this unwavering allegiance to classical Islam to consolidate vis-e-vis various splinter groups that made into the region both through oceanic networks and sub-continental roots. Other than Mujahid and Jama'ath-e-Islami, sub-continental born varieties of Tableeg Jama'ath, Deobandi sects, Ahl Hadith and divergent Tariqahs that made their way into Kerala from the time period of $18^{\text {th }}$ to $21^{\text {st }}$ centuries faced the more or less same

\footnotetext{
19 al-Sayyid, al-Haqq al-Mubīn, 183-193.

${ }^{20}$ Dar al-Ifta al Misriyyah, "The Concept of “The Ummah"," Dar Al-Ifta al Misriyyah, accessed January 21, 2021, http://www.daralifta.org/Foreign/ViewArticle.aspx?ID=367\&CategoryID=3.
} 
antagonism of classical imprint. A great deal of this continuity owes to the peculiar educational system of this region that favoured formation of rigid ideological and Isnād/Ijāza network through student-teacher relationships, allowing the head teacher to prudently and selectively assure that only those ones who subscribe to his ideological lineage are socially and culturally legitimized for taking the religious message forward. The panIslamist connections reworked in the earlier period of British colonialism and during the Khiläfah Movement of 1921 and the fast flocking of Keralite students to Islamic higher education colleges in the rest of the country since the late $19^{\text {th }}$ century were events that stifled this order and bought down the current of reformism and alternate networks of knowledge creation to this region. In the post-colonial period of counter-resurgence where reformist groups constantly entertain narrative-breaks to keep pace with the postmodern precariousness of norms, the traditional scholars have yet again found that only the indigenously poised traditions of classical methodology could withstand the tides of legal-political culture of the modern state and its pluralist narratives.

\section{The concept of Ummah among Traditional Kerala}

Kerala society is a predominantly plural society encompassing striking variants in culture, social and religions domains. Muslim identity construction in a society brimming with diversities was a herculean task before traditional Ulama. As a high spot to Arab merchants due to its maritime relationships, the regional life style of those who engendered Islam in Kerala was not a novelty to Keralites. The past of the state thus provided ample space for Muslim identity construction in Kerala. However, as Stuart and Weber did contend, further developments too had defining effect, both positively and negatively. ${ }^{21}$ In fact, traditional Ulama for their identity construction employed a genre of cosmopolitanism that imbibed trans-historical and trans-geographical Muslim imaginations that are constantly negotiated with global Islamic corporates and local social corporates they are part of, thereby

${ }^{21}$ Abdussathar, Kerala Muslim History Conference Proceedings (Kerala: Islamic Publishing House, 2015), 786. 
initiating themselves in to a global structure that facilitated translocalization of narratives and authority.

\section{The question of the political and the geographical}

Though religious platforms was a major outlet for Ulama interventions, from its outset. an absence of well-heeled Muslim state had necessitated Ulama intervention on political affairs as well ${ }^{22}$. Verily, these interventions were contextual application of Islamic political values. With an effective deploying of Muslim Ummah identity, traditional Ulama acted as uncompromising defenders of regime under Zamorin against colonialism and went for brilliant blend of Muslim interests with interests of local polity. Mappilas received ideological underpinning for their struggle from Islamic textual and discursive forms. Legal and theological theorization could be discerned behind all struggles they engaged. A bunch of Fatwas and those anti-colonial texts i.e., Thahreedh of Zainudheen Kabir, Thuhfathul Mujahideen of Zainudheen Sagir and Udhathil Umara of Sayed Fazal and Muhimmathul Mu'mineen of Pareekutty musliyar were authoritative attempts to instill anticolonialism a religious motive and wed the local with global, particular with universal. They glorified physical jihad as an antidote to draconian acts of the arch enemies of Muslims in postcrusade era i.e., imperial western powers. ${ }^{23}$

This phenomenon was never confined to Malabar, rather was something homogenous to almost all anti-colonial struggles Muslims engaged throughout the country. Lord Mayo, for instance, revealingly posed a question to W.W Hunter regarding anti colonial sentiments among Muslims far flung the country

22 Though Arakkal Muslim state under Ali Raja in the northern Kerala was a political and naval power during the $16^{\text {th }}$ and $17^{\text {th }}$ centuries, there geographical control was limited.

${ }^{23}$ There were however certain reservations with regard to jihad extortion in the later periods of National struggle. A number of scholars in the early $20^{\text {th }}$ century, including co-founders of Samastha, manifested pro- establishment view that tried to engage with British officials and abstained from violent forms. Thus, during the Mappila Rebelllion of 1921-22, a number of scholars who gave prominence to public order rather abstained and some were vocal against the rebellion. 
"Are the Indian Musalman bound by their religion to rebel against the queen?" (The Indian Musalmans - W.W Hunter). In his discourses on the issue, K.M Panicker answer this as follows: In the background of growing resentment among traditional Ulama over cultural and religious imperialism of colonial government, Ulama found rejuvenating culture and religion an imperative. In such a circumstance, its usual that their religious preaching were characterized with anti-colonial elements. As the ideological world of Mappila Muslims was in the circumference of Ulama's dictation, Mappila Muslims ${ }^{24}$ gained momentum for their social movements from same ideological world. ${ }^{25}$

Traditional Ulama had made resolute commitments and illuminating contributions for anti-colonial struggles by employing the binding force among Muslim Ummah. The driving force behind Zamorin relation with sultan of Egypt and other Arab leaders were Maqdooms. Zamorin availed help from Maqdooms for writing letters and keeping a rich relationship. ${ }^{26}$ These developed into even Maqdooms sublime influence in mobilizing Muslim leaders around the world against colonialism and attribute this mindset for enlivening anti colonial movement in Kerala. Likewise, Arakkal state in 1777 and later in 1780 under Ali Raja Kunhi Hamsa II was also said to have links with Uthmania Khiläfah in its expedition against colonial powers, namely Britain and Portuguese during Second Anglo-Mysore Wars. These letters also mention earlier assistance the region have received two hundred and forty years ago by Hadim Suleiman Pasha. ${ }^{27}$ It's to be noted that ideas of nationalism and secularism were either not in existence or was only in its proto period with no established form. By then, Mappila mindset was based on apparently oversimplified notion of hostility towards any powers curtaining religious

${ }^{24}$ A community of Muslims residing predominantly in North Kerala and Lakshadeep Islands, who may be descendants of native converts or mixed descendent of Arab or non-Arab individual.

${ }^{25}$ Kasim Irikkur, Kerala Muslim, 312.

${ }^{26}$ Husain Randathani, Mappila Malabar (Calicut: Islamic Publishing Bureau, 2008), 20.

${ }^{27}$ Saifudheen Kunj, Kerala Muslim, 255.. 
freedom and liberty and brotherhood with those powers rendering those liberties. ${ }^{28}$

Traditional Ulama's response to Turkish Khiläfah was something that solved much of enigma persisted during that period. As a major throne holder in the Muslim world and a bearer of tradition, traditional Ulama through various epochs have given legitimization to Turkish caliphate's leadership both in religious and political form. Ideological and diplomatic reciprocities were sufficiently used by both parties with no contradiction with local interests, rather they produced progressive elements. In a letter addressed to madras govt. from F.C Brown, a merchant, the sentimental relationships Mappilas had with Turkish Khiläfah is explicitly cited. ${ }^{29}$

Sayed Fazal Pookoya 's role in fostering this relationship is noteworthy. The strong anti-British posture helped him gain the attention of Ottoman Empire and to receive the recognition "Arab notable" and the title "pasha" with an official salary from Istanbul. ${ }^{30} \mathrm{His}$ interventions often had decisive role in influencing sultan Abdul Hameed's stance on Islam and Arab region. While acknowledging him as an ardent advocate of expanding and cementing ottoman Khiläah for Muslim revivalism in the face of stiff opposition from Europe, the fact that he championed Hindu Muslim brotherhood in Kerala context should never be set aside. His influence wedged deep into society, to an extend that M.H. Ilias point out his death ignited a mobilizing in Malabar which culminated in more serious Mappilas rebellion of $1921 .{ }^{31}$ It is

${ }^{28}$ Randathani, Mappila Malabar, 34. This is particularly interesting not only because of the difficulty in attesting the category of religion and secular, revealing its roots in a particular phase of early modern European history to nonwestern environments and the ideological and cultural bias in this venture, but also because later post-colonial Muslim political discourse had different political equations that evolved from their status as minorities facing charges of sedition and reinstated their political passivity.

${ }^{29}$ M Gangadhara Menon, The Malabar Rebellion 1921-1922 (Allahabad: Vohra Publishers \& Distributors, 1989), 69-70.

${ }^{30}$ M.H. Ilias, "Narrating the History of Malabar's Omani Connection with Special Reference to the Life Histories of Cheraman Perumal and Saiyyid Fadl Moplah" (Presented at the Malabar Arab Relations, Oman, 2011), 13.

${ }^{31}$ Ibid., 21. 
important to note here that earlier discussions regarding the events of 1921 did not debate much about the Mappila outbreaks of $19^{\text {th }}$ century forming the background of the 1921 Rebellion. While William Logan's 'Malabar Manual' published in 1887 treat these outbreaks at considerable length, its timeline did not cover the whole story. Contemporary scholars also argue that treating the rebellion through watertight compartments of religious fanaticism as the British has done or through economic considerations as the leftist historians have done are bound to fail. Social marginalization, political aspirations and occupational variances with regard to various communities come into play in this question. 32

Broadly, Kerala Muslim's sentiments and feelings for Uthmania Khiläfah were once again incarnated in national freedom struggle by traditional Ulama along with leaders in political sphere. They rendered financial aid to turkey through Indian medicine mission and Red Crescent society, spiritual assistance through prayers and diplomatic support. ${ }^{33}$ Further, Mona Hassan argues that Indian Muslims themselves expressed a collective sense of ownership in the Ottoman Caliphate that they, as others from Muslims lands, thought that it was not within the power of Turks alone to abolish Ottoman Caliphate. While Indian Caliphate committee could have relapsed into utter dismay following their failure to revamp Caliphate, the convergence that religious scholars worked out during this period would soon become an ideal India that Muslim democratic parties and even leftist liberals point to during intra-communal tensions. For their part, traditional Ulama by knitting hands with nationalist leaders was providing a convergence point for Quranic concept of Ummah and allegiance to nation-state.

In an alternative reading, these attempts looming out of affinity for a region or nation, in fact helped in bringing global

\footnotetext{
${ }^{32}$ For further reading on the complicated background of Malabar Rebellion see M Gangadhara Menon, “Mappila Outbreaks of 19th Century Malabar (The Background of the Malabar Rebellion of 1921)," in Proceedings of the Indian History Congress, vol. 33, 1971, 483-493.

33 Saifudheen Kunj, Kerala Muslim, 256.
} 
Muslim Ummah together. As Frederick Dale notes regarding construction of political mindset of Mappilas Muslims during Portuguese invasion, anti-colonial struggles provided a common platform for Muslim Ummah to deliberate and frame strategies as an antidote for shared historical experience of crusades ${ }^{34}$. Thus, the concept of Islamic Brotherhood, a feeling imposed from outside is established through "Asabiyyah" (group feeling) for the betterment of community. ${ }^{35}$ Wholly speaking, it is creditworthy that traditional Ulama, striving for global integration of Ummah, in their political perception had imbibed the typical social environment of Kerala that transcended the watertight compartment of sacred geographies.

In the present political context, gaining inspiration from earlier responses, Samastha Kerala (Sunni) 36 Jam'iyyathul Ulama -as an organization of prominent traditional Islamic scholars formed in 1925 in opposition to organizational capacity of the reformist-Salafist Aikya Sangam- played a key role in dictating pluralist culture of Ummah from the onset of $20^{\text {th }}$ century. While enlivening Ummah identity in contemporary world by close contacts with international Ulama bodies and Muslim political leaders worldwide through its leaders with international stature, Samastha continuously make Muslims of Kerala aware of involvement in elections as a political right and assert their nationalist credentials. ${ }^{37}$ Aftermath the 1989 split in the Samastha

\footnotetext{
${ }^{34}$ Kasim Irikkur, Kerala Muslim, 312.
}

${ }^{35}$ Asyiqin Ab Halim, "Ibn Khaldun's Theory of Asabiyyah and the Concept of Muslim Ummah," Journal of Al-Tamaddun 9, no. 1 (June 30, 2014): 41. Similar tendencies to equate the liberation of Ottoman empire with colonial resistance and nationalist aspirations could even be found in former Ottoman provinces. Ahmed Shawqi's lines during this period for instance signified the loss of last great Muslim power in the age of encroaching colonialism while echoing his own nationalist aspirations for Egypt. See Mona Hassan, Longing for the Lost Caliphate: A Transregional History (Princeton, NJ: Princeton University Press, 2016).

36 The term 'Sunni' is officially used along with 'Samastha Kerala' by the breakaway AP faction from 1989. The remaining EK faction continue to limit themselves to 'Samastha Kerala'.

37 Such demonstrations often get mired in polemics related to state's attempt to manipulate and stipulate religion and minority into prescribed role. The World Sufi forum of All India Ulama and Mashaikh Board (AIUMB) in March 2016 
underpinned by alleged political party intervention, these two segments have been independently employing their discretionary power for bargaining better treatment of Muslims and often criticizes politicians of their immoral conduct. Nevertheless, the two factions, namely AP (named after Kanthapuram AP Aboobacker Musliyar) and the residual EK (named after factions are historically seen to be aligned with CPIM-led Left Democratic Front and Indian Union Muslim League respectively during elections, though the former had more political independence owing to its non-conformist views with regard to Muslim League, the official partner of erstwhile Samastha and 'unofficial support' to a secular party. However, the bodies at the same time are vigilant of political powers intervention in its internal matters and dictating Muslim- religious affairs and leaders like AP Aboobacker Musliyar and Sayed Jifri have been vocal about this.

This bifurcation is well paid off for peaceful Muslim identity in a plural society in contradiction with organizations such as Jamaathe-Islami and erstwhile Popular Friend of India (PFI) who handle them together, thus succumbing to problems stemming from over politicalization of religious concepts. The JamaatheIslami, with its hitherto prescribed objectives of achieving Hukumat-i-ilahi, a religio-political state proposed by its founder Maudoodi, had earlier rejected modern secular state. ${ }^{38}$ Though it set out for accommodation in the Indian context, on the question of relationships between Islam and nationalism, it often revealed contradictions in its public pronouncements. A.L. Islahi, a former Ameer of Jamaath even recently denounced nationalism. ${ }^{39}$

inaugurated by PM Modi and attended by Kanthapuram AP Aboobacker Musliyar became a political tool for Salafi-reformists to slam Barelwi Muslims in North India and their counter parts in Kerala for succumbing to Hindutwanationalist agenda. To further find how religious polemics are closely aligned with state regulation of religion, see Nandagopal R. Menon, "What Do Polemics Do? Religion, Citizenship, and Secularism in South Indian Islam," History of Religions 58, no. 2 (November 1, 2018): 128-164.

38 Tanweer Fazal, "Ummah, Qaum and Watan: Elite and Ordinary Constructions of Nationhood among Muslims of Contemporary India" (CAS Working paper series, Jawaharlal Nehru University, New Delhi, 2014), 6, https://www.jnu.ac.in/sites/default/files/u63/tanweer-paper.pdf.

${ }^{39}$ Ibid., 9. 
Similarly, PFI's strategy sit in close tandem with Muslim brotherhood in Middle East (Ikhwan-Ul-Muslimeen), a recipient of Sayed Qutub's notions. In the Salafist paradigm embraced by Kerala Mujahids, Islam has been constructed as a political force that might transform Ummah and provide a basis for Islamic identity in Muslim struggle against neo - colonialization. ${ }^{40}$ Various avatars of these organizations are increasingly under probe for their alleged relationships with extremist organizations and indoctrination of such ideas in youth ${ }^{41}$. Nevertheless, it is uncertain in no terms that one of typical character of classical continuum of Muslim Ummah is moderation which traditional Ulama always pursue. In interpreting the word "a middle nation" in the verse 2:143, Al Tabari says: the word "made you middle" means that we were customized to be a moderate nation apart from followers of all other faiths. The Islamic faith is moderate without the exaggerated austerity of Christians and or the utter leniency of the Jews who changed the words of their prophets and killed them. The Muslims are moderate and middle as befitting the definition that Allah gives them and the best of anything is its. ${ }^{42}$

\section{The Islamicate imaginations: cultural and knowledge landscape}

As a code of conduct for heterogeneous community of humans, Islam proposed cultural division in its sharia edifice. Islam as it reached various pockets had assimilated with local culture on one side and tried to mould up culture suited to its proliferation on the other ${ }^{43}$ Islam in these locations legitimized local culture derived from other communities with a prerequisite that it is supported by broad walls of Sharia. Urf (local culture) is often taken as reference in those situations. Since claims of 'true or pure islam' and questions of authentic Islamic sensibilities and

40 Ronjoy Sen and Robin Jeffrey, Being Muslim In South Asia: Diversity and Daily Life (Oxford: Oxford University Press, 2014).

${ }^{41}$ See Megha Varier, "Voice Note by ISIS Terrorist Declares Peace School in Kerala Has Their Supporters," The News Minute, last modified April 10, 2018, accessed March 12, 2021, https://www.thenewsminute.com/article/voice-note-isisterrorist-declares-peace-school-kerala-has-their-supporters-79345.

42 al-Ṭabarī, Jāmi' al-Bayān, 141-142.

${ }^{43}$ Randathani, Mappila Malabar, 23. 
practices stand at the crossroads of traditional and reformist usage of the Ummah-the global Muslim culture, I will attend to this debate from a framework that M.S. Visakh et al has recently articulated by the concept 'true Islamicate global imaginations'. Visakh says "While the reformist claims of 'true Islam' carry a global Islamic impulse towards purification that seeks to disembed religious practices from cultural specificities, 'true Islamicate global imaginations' envisage Islamic religious practices as embedded within the cultural context of its existence across diverse geographies". ${ }^{44}$ The culture of Ummah is reflected within such islamicate imagination of localities that defy geographical boundaries through, as Arjun Appadurai says, "a series of links between the sense of social immediacy, the technologies of interactivity and the relativity of contexts". ${ }^{45}$

Cultural integration of Muslim Ummah in the Keralite Muslim context, should now be read from such a framework of local culture becoming an element of global Muslim culture whose universal characters stem from its accumulation of diverse social and cultural complex across geographies. Traditional Ulama envisaged a hybrid form of pure Muslim culture and prevalent Kerala culture to formulate a local Islam. Rather than going for an utter overhaul of persisting parameters, this maneuver was necessary to accommodate culturally defiant new members into Islam. Thus, Islamic culture in Muslim regions, namely Arabia and Persia were slowly integrated with local culture. This process, scholars argue, gradually facilitates a creation of pristine Islamic culture.

Muslim Ummah identity is also knowledge based and knowledge oriented. Principle of divine unity, as a defining element of Ummah pertains to witnessing of absolute truth and thus to the highest knowledge which is the principal container and generator of all human knowledge. And the principle of Muhammadan apostleship witnessed through the most important

\footnotetext{
${ }^{44}$ Visakh, Santhosh, and Roshan, "Islamic Traditionalism in a Globalizing World," 35.

45 Arjun Appadurai, Modernity at Large: Cultural Dimension of Globalization (Minneapolis: University of Minneapolis Press, 1996), 189.
} 
cosmological and societal truth as the second defining element is also knowledge oriented. ${ }^{46}$ Quran summed it up "It is he who has raised among the unlettered people a messenger from among themselves who recites His revelations to them, and purifies them, and teaches them the Book and wisdom, for they had formerly been clearly misguided-" ${ }^{47}$ Further, the essential attributes of Ummah mentioned in the verse 3:10 i.e., Al Maaruf, Al Munkar and faith in God are all knowledge based. As the network of Ummah become sophisticated, what were demarcated as munkar and maaruf also increase in scope, resulting into scholars developing Islamic jurisprudence into a major science ${ }^{48}$ This clearly envisages knowledge as fundamental practical criteria of Ummah concept. This is considered to be why traditional scholars of Kerala were much indulged in spreading knowledge en route greater cultural and political integration of Ummah.

Trade routes between Malabar and those repositories of Islamic culture, which further fashioned into a Sufi religious route was instrumental in this process. Abu Lughod ${ }^{49}$ argues that there existed an "oriental global system" long before European advancement, this was employed by Sufi saints especially Hadhrami and Bukhari sadaths. ${ }^{50}$ In a similar way, Sufi saints in Malabar had scholarly relationships with Arab world. Sheikh Zainudheen Kabir was graduated from Al Azhar, while sheikh Zainudheen Sagir was graduated from Imam Ibn Hajar Al Haithami, whose Dars ${ }^{51}$ in Mecca was globally renowned. He is too said to have laid the foundation stone for Ponnani mosque. Experiences and flavors from these journeys culminated in

${ }^{46}$ Osman Bakar, "The Qur'anic Identity of the Muslim Ummah: Tawhidic Epistemology as Its Foundation and Sustainer," Islam and Civilisational Renewal (ICR) Journal 3, no. 3 (April 2012): 443-444.

${ }^{47}$ Al-Jumu'ah 62:2.

48 Bakar, "The Qur'anic Identity of the Muslim Ummah," 445.

49 Janet L. Abu-Lughod, Before European Hegemony: The World System A.D. 1250-1350 (Oxford: Oxford University Press, 1989).

${ }^{50}$ Generally, a suffix given to the descendants of Prophet Muhammed

${ }^{51}$ A Muslim educational platform centered around a Mosque and under a renowned scholar assisted by his associates. Teacher-disciple relationship takes prominence in those institutions 
fashioning a Dars system with a structured syllabus. Knowledge seekers from foreign countries such as Egypt, Syria and other parts of the country attended those Dars, while historical anecdote points to eminent scholars from Yemen, Egypt, and Hejaz who are said to have conducted classes at Tanur Dars. ${ }^{52}$ Also, since there existed a "text-centeredness" in Islamic tradition, a continuous tradition of textual longue-duree, to use the concept of Fernand Braudel, between the geographical Middle East and Indian Ocean rim in the Shafi jurisprudential tradition allowed scholars like Zainudheen to engage in dialogue with larger Islamic world through their own commentaries and super commentaries. This is often facilitated through "dialogic texts" like the Tuhfat of Ibnu Hajar, a $16^{\text {th }}$ century commentary to Imam Navavi's influential work Minhaj that displays the style of a teacher-student dialogue when making elaborations. Zainudheen Sageer arguably has his own super commentary on the same titled "Fathhul Mueen BISharahi Qurrathul Ain" which connects to the Shafiite clusters of classical Islamic realm through the genealogical network of Tuhfat$u l-M u h t a j .{ }^{53}$ Sufi orders, especially the four prominent orders and their offshoots that worked with extensive links through their shaikh-murid sanad worldwide were deeply rooted in Kerala and thus played no small role in molding up a coherent Muslim awareness ${ }^{54}$. These indigenous scholars responded to the pulses of global Muslim through their religious interventions and scholastic works such as Thuhfathul Mujahidin and Fathhul Mueen which were

52 Islamic Publishing House, ed., Islamic Encyclopedia Malayalam (Kerala: Islamic Publishing House, 2005).

53 For further reading on dialogization between Middle East and other Islamicate lands facilitated by this textual longue-duree, see Mahmood Kooria, "Cosmopolis of Law: Islamic Legal Ideas and Texts across the Indian Ocean and Eastern Mediterranean Worlds" (Doctoral Dissertation, Leiden University, 2016), https://www.academia.edu/30069524/Dissertation_Intro_Cosmopolis_of_Law_Isl amic_Legal_Ideas_and_Texts_across_the_Indian_Ocean_and_Eastern_Mediterra nean_Worlds_.

54 Randathani, Mappila Malabar, 22. However, Sufi-orthodox rivalries including the infamous Kondotty-Ponnani debates in $18^{\text {th }}$ century created ambigious positions within Keralite Muslims though predominantly, Sufiorthodox tradition have went hand in hand. 
originally written in Arabic language, reflecting their global Ummaistic character.

Maqdooms ${ }^{55}$ further implanted Persian tradition prevailed in Yemen to Keralite context. Many words in Arab Malayalam, which finds its etymology to Persian language, bear testimony to this fact. ${ }^{56}$ Arabi-Malayalam, a vernacular Dravidian language of Mappila Muslim community with lexical admixture from Arabic and Persian, was another traditional Ulama venture aimed at resolving the hybrid Ummah, a local Malabar Islam deeply in conversation with global variants. In a complex atmosphere of weighing Muslim treatment of Arabic as their religious language and Malayalam as their mother tongue, traditional Ulama employed Arabi-Malayalam for their literal-scholarly transactions. Even the everyday self-making and philosophical thoughts were Arabi-Malayalamatized. Arabi-Malayalam encompassed Quranic exegesis, jurisprudence, Sufi songs, and prophetic thoughts etc. In the view of CK Kareem, Arabi Malayalam was vast in literal scopus than Malayalam before one century. However, reformists view it as a 'trap of duality' and a dormant language of no use in future while conveniently avoiding the historicity that necessitated it and its perceived role in transcending marginalization of Muslims.

Along with this, many other local sensibilities and imaginations found space into Muslim lifestyle. Masjid-forms which resembled with architecture of Hindu temples, practice of naming children with locally sandwiched names such as Pookoya and Kunjikoya, and dress codes of men and women which was a combination of Yemen, Turkish, and Keralite dress codes, were in this direction. Be that as it may, ventures of Sufi scholars such as Sayed Fazal, who were prudent of non-Islamic cultural acculturation, played a decisive role in Muslim community as a whole distancing from hitherto followed Hindu-local traditions. ${ }^{57}$

${ }^{55}$ A renowned lineage famous through scholars in Ponnani region including Zainudheen Kabir and Zainudheen Sagir. The family moved from the Kayalpattnam area in Tamilnadu to Kochin, and then to Ponnani during the period of Zainudheen Kabir.

${ }^{56}$ Randathani, Mappila Malabar, 24.

${ }^{57}$ Ibid., 25. 
There have been many instances of Muslim culture becoming an indelible part of whole Keralite society. The idea of organization as a society, if not under a leader, was introduced by Muslims coming into the subcontinent with heavily interwoven social and religious matrix. Half-naked costume traditions, including the inhuman practice of topless costume for Dalit women started to pick up a gradual change as a part of largescale conversions of lower working class along with other class resistance movements. And after all, Muslim resistance culture motivated by discursive scriptural traditions instilled a sense of resistance against injustice into the social-behavioural culture of Keralites. In nutshell, with increasing influence of Hadhrami and the like, Kerala Muslims began to share Muslim discourses and cultural products which characterized most of Muslim communities scattered along East Asian countries where Hadhrami have settled including Indonesia, Malaya, Java, Singapore, Timor and the Hadhramaut itself. 58

\section{Trans-localization of Sacred, Dialogue and Authority in Post 20 $0^{\text {th }}$ century era}

In the second half of twentieth century with a looming atmosphere tinged with Islamic character, traditional Ulama has been engrossing much on globalizing local Islam and vice versa. In lieu of oriental global trade system of Indian Ocean, more encompassing structural as well as cultural forces of globalization process underpinned this change. Along with the growth of neoliberal economy and the development of electronic and digital media networks, heightened transnational connections and global intellectual and political flows bought a paradigmatic transformation within how reformism and traditionalism are ideologically bracketed in enlightenment imagination, i.e., reformism as a progressive notion and traditionalism as its nonmodern other. However, as Humeira Iqtidar notes "(this) is redundant in the face of new generation of scholars who are keen to be defined as traditionalists or at least as being closely bound to

\footnotetext{
58 Jaleel, Kerala Muslim, 93.
} 
the tradition" while making immense use of modern globalization tools. 59

A change initiated by 'reflexive and communicative' dynamics of globalization began with as Peter Mandaville says, changes in" textual forms, discursive forms and personification of authority" that bought new global-Ummah elements into what is authoritative in local Islam. ${ }^{60}$ Muslims started checking their own culture and changed the architecture of Masjids to Mughal-Persian variants popular in north India and recently, Arabian architectural models bought from Gulf networks. Contrary to family tradition of sandwiched names, pure Arabic names are in circulation all through the Kerala. In naming Masjids with Arabic and elements of Islamic and islamicate imaginations such as Masjidul Athaar/Masjid Sha'are Mubarak, ${ }^{61}$ a globalization of Ummah identity is exposed. Cultural and religious programs are increasingly been bestowed with global nomenclatures such as "International Meelad conference" and "Hubbu Rasool conference". Muslim students and scholars are heavily borrowing Arabian dress codes which crowns them with a global character. The one used mostly by AP faction include a long robe with turban wrapped around their head in a distinct manner and is practiced with an Ijazah from Yemani scholars. In the face of severe opposition to commercialization of religion and 'arabization', such reciprocals require religious leaders to tight trope between sanctified cultural symbols, political culture, economic rationale and spiritual elements to not blur the lines between different elements. Kanthaparum AP Aboobacker Musliyar, for instance, faced heavy censure from almost all Muslim organization when in 33rd Markaz Conference he announced possession of a lock of 'holy hair' of prophet from Shaikh Ahmad Al Khazraji Abu Dhabi. Even the traditional EK

59 Humeira Iqtidar, "Redefining 'tradition in Political Thought," European Journal of Political Theory 15, no. 4 (September 16, 2016): 426.

${ }^{60}$ Peter Mandaville, "Globalization and the Politics of Religious Knowledge: Pluralizing Authority in the Muslim World," Theory, Culture E Society 24, no. 2 (March 1, 2007): 101-115.

${ }^{61}$ A Grand Masjid of Rs 400 million budget proposed by AP faction to house the holy relics of Prophet Muhammed including the holy lock of Prophet's hair currently housed in Karanthur Markaz, Calicut. 
factions came out with a public statement accusing him of commercializing religion and 'deceiving believers in the name of Prophet's hair'.62

This pluralization of authority however synchronistically cultivated closer binds vis-e-vis reformist and secular imaginations. The supreme body of Samastha, the Mushawara, constituting 40 well versed scholars representing different Muslim pockets of Kerala and its public capacity with regard to political, cultural and religious issues engendered the Keralite manifestation of Prophet Muhammed's prophecy about Muslim Ummah: "Allah never unite this nation on aberrance and the hand of Allah is with the group" (al-Tirmidhi). Samastha had organized scattered Muslims under a leadership, thus helping them to develop as Muslim community in India.

From its inception, Samastha followed a two-prong approach aimed at insulating all the non-Islamic rituals that cannot be aligned with Islamicate imaginations while also defending its local Islam from puritan sects i.e., Mujahids ${ }^{63}$ and false Tarīqahs in its course towards a pristine Islamic system. In recent years, its various offshoots have been addressing issues of Indian Muslims and global Muslims as well. Apart from religious and spiritual interventions, it offshoots too engage in relief and humanitarian works far flung the country and abroad. As a result of shared faith and Ummah identity, it's said that Islamic relief organization are more successful in its outreach to Muslim refugees than other faith-based organizations or secular organizations. ${ }^{64}$ The AP faction among the Samastha carry out their humanitarian work through Relief and Charitable Foundation of India (RCFI) which on the other hand is funded by global charity establishments like Red Crescent, al Rahma, and Dubai Charity etc. A glance through

${ }^{62}$ P. K. Asheem, “'Holy’ Hair Brings Merger Talks Between Kerala Muslim Bodies to a Halt," News18, last modified November 16, 2018, accessed March 10, 2021, https://www.news18.com/news/india/holy-hair-brings-merger-talksbetween-kerala-muslim-bodies-to-a-halt-1941137.html.

${ }^{63}$ A term used generally for all Salafi-Wahabi reformist groups in Kerala probably emanating from Kerala Nadvathul Mujahideen founded in 1952, the successor organization of Aikhya sangam, the first Salafi organization in Kerala.

${ }^{64}$ Kadiruzzaman, Islam Without Borders, 23. 
brochures of RCFI shows how they cultivate global pious Muslim subjectivities through neoliberal notions of global entrepreneurship that transverse state institutions. ${ }^{65}$

Traditional scholars were also engaged in pluralizing educational flavors and syllabi employed at abroad in the local seminaries to keep pace with vertically and horizontally polyvalent discourses and predicaments. Chalilakath Kunjahammed Haji during his stint at Darul Uloom Arabic Colllege Vazakkad attempted to reinvest in the Othupally-Dars system through an improvised Madrasa system ${ }^{66}$ by reintroducing subjects such as Arabic language, Arabic grammar, philosophy, rhetoric, history, geography, astronomy and engineering etc. to transcend the conventional Dars system which has turned into bare skeleton of knowledge. He too introduced teaching tools and specific examination system being inspired by educational system outside Kerala ${ }^{67}$. Modern madrasa movement began in 1950s and later, an integrated education approach (matha-bhauthika samanwaya vidyabhyasam) began in 1980 s with the first model Dars being established in Kottakkaal Town Juma Masjid that incorporated subjects such as Urdu and English language into curriculum. Another group of institutions, Shariath colleges, being inspired by the models of Darul Uloom Deoband in UP and Baqiyath Al Salihath Arabic college in Tamil Nadu were established as new avenues to impart religious higher education in Kerala. Most recently, Da'awa colleges with integrated approach are embarked upon with special reference to propagational requirements. These educational conglomerates such as Jamia

${ }^{65}$ One of the brochures reads "One need not wait for the governmental system to reach aid and assistance to the adversely affected and provide education to the unprivileged. These are now personal responsibilities of each individual, more of business issues and the corporate leaders than the politicians." Relief and Charitable Foundation of India, 'Share to Care', available at http://www.rcfi.in/Brochure.pdf [accessed 15 March 2021).

${ }^{66}$ During the last phase of colonial rule, numerous Madrasas sprang up in lieu of Othupalli system which were increasingly commissioned as secular schools in the aftermath of 1921 Mappila Rebellion, possibly to combat 'religiousfanatism' among Mappila community.

${ }^{67}$ Randathani, Mappila Malabar, 27. 
Markaz, Darul Huda, Jamia Nooriyya and Ma'adin have signed MoU with international Islamic universities such as Al Azhar Cairo, International Islamic University Malaysia and Zaitouna University Tunisia etc. and exchange their students and pedagogies each other for fashioning a coherent global Muslim educational experience. Darul Huda is also an ISO 9001:2015certified institute of higher education and a member of the Federation of the Universities of the Islamic WORLD. There is a steady growth in traditional sponsoring of Arabic teaching and Arabic journals which were hitherto dominated by Arabinfluenced reformist voices in those institutions. Magazines such as Assaqafa from Jamia Markaz, Annahda from Sabeelul Huda Arabic College and South-al-Jamia from Jamia-thu-Hind-AlIslamiyya have scholastic and popular recognitions. Though traditional Ulama frequented Arabic grammar and literature for a long time owing to their discourses in Islamic literature, post $20^{\text {th }}$ century era witnessed committed ventures tailored to produce Arabic speaking scholars who could intervene in international society and forums.

Wholly speaking, these initiatives were to promote Da'awa and dialogue for Muslim Ummah which is fast assuming currency in the global Islamic proselytizing phenomena. The pivotal task for Ummah is the very essence of Da'awa /invitation to the message through committing to this part of reference in collective and individual behaviors. This commitment is the means to achieve the objective of being "a witness for mankind" mentioned in the verse 2:143 regarding Ummah of prophet Muhammad (s). Ummah is invited to deliberate with the other communities for the same in a way stated in Quran: "Call to the away of your lord with wisdom and fair exhortation and reason with them in a way that is best" ${ }^{68}$ Various interfaith and intra-faith dialogues initiated in individual and group capacities are considered as a catalyst and vehicle for attaining Da'awa. ${ }^{69}$ In addressing the political role of dialogue, anthropologist John R. Bowen argues that "transnational Islam creates and implies the existence and legitimacy of a global public

68 An-Naḥl 16:25.

${ }^{69}$ Dar al-Ifta al Misriyyah, "The Concept of "The Ummah"." 
space...of debate and that space cannot be reduced to...migration or transnational religious movements". Bowen looks on to the third category of developing dialogues and discussions among Muslims concerning the nature and position of Islam in Europe and North America. While analyzing these discussions around problems faced by Muslims in being a part of western society along their Islamic cultural baggage, he notes intrinsic universality of religion or in Islamic terms, the Ummah that is best negotiated through political dialogues. ${ }^{70}$

In the plural Keralite context, traditional Ulama are heavily involved in staging international dialogues on global Muslim issues even if they are not concerning to Kerala Muslims. While public fathwa culture is not so prevalent among traditional Kerala scholars as they are among North Indian and a number of foreign scholars who are often part of government religious institutions, they do make constant comments through social media, mainstream media and official letters, sometimes inviting political and religious response from global authorities. ${ }^{71}$ It is evident that they have severed their earlier subservient nature of peripheral scholars and had recently begun to command global Muslim leadership. Three of Keralite Muslim scholars namely, Kanthapuram, Bahauddin Nadwi and Sayed Khaleel Bukhari were featured in The 500 Most Influential Muslims published by Royal Islamic Strategic Studies Centre in Amman, Jordan. Kanthapuram was recently conferred the title of Grand Mufti of India, a long pejorative of North Indian Muslims, in a February 2019 Garib Nawaz Peace Conference organized by All India Tanzeem Ulamae-Islam following the death Akthar Raza Khan Barelvi. The title

${ }^{70}$ John R. Bowen, "Beyond Migration: Islam as a Transnational Public Space," Journal of Ethnic and Migration Studies 30, no. 5 (September 1, 2004): 879 894.

${ }^{71}$ Fatwa is a non-binding legal opinion on a point of Sharia given by a qualified jurist in response to a question posed. Often, they are taken up by the jurist or the concerned law organization on their own to address a publish issue. The supreme body of Samasta, Mushavara has produced a number of fatwas related to heretical sects, Islamic economics etc. while they usually abstain from producing Fatwa on contemporary political and social matters that are not seriously concerning. 
bought him a new platform to religiously sanctify and socially expand his influence while also inviting searing umbrage from local factions vary at the possible power-shift. Among others, there is now a consecrated attempt to brand his name in an arabized and Islamized form to pronounce Shaikh Aboobacker Ahmed while his Sahih Bukhari sessions are now designed as a global event.

Peace conferences such as one named after Sheikh Zayid Al Nayhan of UAE, international Da'awa conferences, anniversaries of prominent institutions Such as Jamia Markaz, Darul Huda, Jamia Nooriyya and Ma'adin Academy are conducted annually or biennially where political leaders and spearheads of international Da'awa ventures such as Taba foundation, Ma'arij institute and Ihsan institute, deans of Islamic universities and envoys of transnational Muslim organizations are regularly invited. Earlier, Arab-international guests were the prerogative of reformists, which has now taken a u-turn owing to the international backlash they received during the alleged ISIS recruitment controversy. Many familiar international faces were also directly instrumental in establishing religious seminaries in Kerala. Kanthapuram explains the role of transnational links with Gulf countries in the establishment of Markaz Saqafat Sunniya (now Jamia Markaz) in 1978:

We did not have many contacts with the Gulf countries during the period apart from a few connections with the Arab ulama. It was through them that we formed a relationship with the ruling class. Syed Muhammad Al Maliki's family runs dars in Masjidul harm for centuries and has fought against the political and religious transition in Saudi Arabia... It was Allah's blessing that we could bring such a person to lay the foundation stone for Markaz ..."72

To expand on Bowen examined with regard to the speeches of international Islamic scholars in the European context, it could be argued that none of these dialogues deferred the national norms or laws, since doing so could be construed as Muslims attempting to "fit Islam into reality" rather than using Islam to "reshape reality". Moreover, existence of such global Muslim space for Ummah

72 Anonym, Markaz Rubi Jubilee Souvenir (Kozhikode: Jamia Markazu Saqafathi Sunniyya, 2018), 27-29. 
showed that many such conferences and dialogues with its attendees coming from ideologically and diplomatically incongruent localities surfaced as a conflict resolution platform for these localities.

\section{Gulf Migration and the Pious Neo-Liberalism}

Migration to gulf countries as an element of globalization process in the post-colonial Kerala gained considerable momentum from 1970s. Arjomand ${ }^{73}$ opines that by contradiction to old pattern of globalization, where religion was the motive force behind globalization, globalization in the $20^{\text {th }}$ century is a much broader process as it is set in motion not by religion but by new cultural and especially technological forces that are entirely secular .In the Keralite context, the children of colonial subjugation sped globalization process towards middle east in an attempt to sustain their families. Be that as it may, the earlier studies bring forth many other valid reasons for such an exponential hike in migration including maritime connections with the Middle East in trade and commerce, religious attachment of Malabar to the Arabia and the ethnic lineages.

To my extend, migration to gulf countries made the community more conscious of its global existence and promoted religion. Beyer (2001) argues that globalization makes religions two major strengths -communal and societal- stronger. He asserts globalization as an effective resource for mobilizing people across the social cleavage such as stratum, class, religion and local culture. ${ }^{74}$ Osella further argues that Gulf migrants are increasingly developing a cognizance to demarcate broader Muslim culture from other cultures. Traditional Ulama are at the forefront of employing this consciousness and their affluent for the betterment of community and rallying them behind global Muslim whole. Gulf migrants are offered the chance of doing good for community and they feel themselves morally accountable to the wider

\footnotetext{
${ }^{73}$ Saïd Amir Arjomand, "Islam, Political Change and Globalization," Thesis Eleven 76, no. 1, TH11 40th Anniversary Collection (February 1, 2004): 9-28.

${ }^{74}$ Mubashar Hasan, "The Concept of Globalization and How This Has Impacted on Contemporary Muslim Understanding of Ummah," Journal of Globalization Studies 2, no. 2 (January 1, 2011): 149.
} 
community. Number of educational institutions and reliefs under Samastha and traditional Ulama are financially supported and ennobled by them. Through these migrants, Arab donors are persuaded with chance of bestowing benevolent generosity to support "backward Muslims" development and participate in the renaissance of Islamic culture and values. ${ }^{75}$ Many top-notch educational institutions under traditional Ulama are fully or partially shouldered by Arab business tycoons. Traditional Ulama regularly pay visit to Arabian countries to cement their relationships with their Arab counterparts and thoroughly make use of amenities provided by Keralite Muslim diaspora dwelling in these pockets. This Ummah consciousness expand into other public commercial centers and educational institutions owned by Muslims that many of them reflect islamicate imagination and sensibilities to an extend of perceiving specially for Muslims. They attract Muslim clients and result in Muslim demographic and occupational concentration around them.

Being exposed to life in technologically superior Muslim countries, traditional diaspora has gone for a blending of their scientific and technological skill-set with Islam. Gulf demonstrates that scientific or technological knowledge need not be in contradiction to Islam but can be mastered for the well-being of Muslims and to strengthen Islam. From a technological vantage point, gulf modernity is taken granted for a Muslim's harmonious relationship with modern forces. ${ }^{76}$ Such maneuvering of social and religious goals of migrants point to an increasing manifestation of what Mona Atia calles 'pious neoliberalism' with regard to faithbased organizations in Cairo, ${ }^{77}$ championing notions of self-help and self-optimizations along with religious self-realization while

\footnotetext{
${ }^{75}$ Filippo Osella and Caroline Osella, "Muslim Entrepreneurs between India \&amp; the Gulf," ISIM Review 19, no. 1 (2007): 9.

76 Caroline Osella and F. Osella, "Nuancing the Migrant Experience: Perspectives from Kerala, South India," in Transnational South Asians: The Making of a Neo-Diaspora, ed. S. Koshy and R. Radhakrishnan (India: Oxford University Press, 2008), 168, https://eprints.soas.ac.uk/5175/.

77 Mona Atia, “'A Way to Paradise': Pious Neoliberalism, Islam, and FaithBased Development," Annals of the Association of American Geographers 102, no. 4 (July 1, 2012): 808-827.
} 
conveniently avoiding structural issues of income inequality within migrants and others

Similar to exchanges dating back to the maritime history, remittance of Arab-Gulf culture which was the official and the first culture of Muslims before the advent of Ajami (non-arab) has greatly invigorated Ummah process. Change in dress code among men and women especially popularity of Parda (Abhaya-Hijab) among Mappila Muslim women came as a result of this migration. These developments are often viewed in negative light by many liberal thinkers who showcase them as part of Arabian imperialism. Though keeping a veil over body as Sharia dictate was never alien to Malabar women before the advent of Parda, ${ }^{78}$ Parda as a dress code imitated by global Muslim community as a whole received global Muslim authority through what Appadurai terms as the trans-localization of authority: 'local idioms of Islam in such contexts find themselves juxtaposed with, and at times challenged by, material from the wider ummah'. With all its advantages, traditional Ulama were aware of the nasty sides of gulf migration that synced well these neoliberal forces. Consumerism have found deep inroads among gulf migrants and their families in Kerala, who succumb to extravagance in their everyday self-making, especially marriages, salkarams, and housing. Extremely vociferous of these developments, traditionally Ulama usually extort migrants to spend them for humanitarian and religious projects, while recent developments also show organizations themselves arranging budget-planning sessions for their followers.

\section{Conclusion}

In sum, the manner in which traditional Ulama worked around the concept of Ummah and invocated a genuinely saturated Ummah culture profoundly resonates similar modelling of 'true Islamicate global imagination' among global traditionalist cycles with the advent of 'the modern'. Our understanding of classical interpretive paradigm on the Muslim Ummah explicitly notes that

${ }^{78}$ Caroline Osella and Filippo Osella, "Muslim Style in South India," Fashion Theory: The Journal of Dress Body \& Culture 11, no. 2-3 (June 1, 2007): 249. 
its existence is solely founded on twin principles of divine unity and Muhammadan apostleship, a trans-historical and transgeographical reality whose articulation is organically reproduced through Ulama and whose norm-creation reflect that of prophet. It doesn't have substantial political implication as Islamist-reformist hermeneutics try to articulate. Nevertheless, we acknowledge presence of some other religio-communal concepts such as the Caliphate in streamlining Ummah consciousness through subtle cross-roads in colonial resistance history and post-colonial idea of state. This spiritual and knowledge-laden edifice of Ummah necessitates epistocratic Ulama negotiation for legitimizing translocalization of Muslim cultural narratives and authority. Our analyses of Keralite Muslim scholars' ventures in political, spiritual, social and cultural realms barefaced a constant negotiation of pre-political local Islamic corporates, religious and political interests and global Islamicate trends with a view to increasingly align with Ummah notion. A gradual development in the localization of global Muslim self-making in the pluralist political atmosphere was facilitated by globalized-neoliberal forces penetrating the volatile notions of the sacred and the welfare, bringing with it a transformation of local social corporates such as the Ulama-spiritual guilds, political leaders and financial class vying for socio-religious power. On the other side, reformists who advanced around 1900s by artificially inserting themselves into the Muslim heavenly command through 'global articulation' and 'true islam' misplaced the boundaries of legal-theological divisions and failed to negotiate with organic religious-political structures to legitimize their 'pure imaginations', consequently succumbing to disintegration and political rejection of their purity norms.

\section{Reference}

Abu-Lughod, Janet L. Before European Hegemony: The World System A.D. 1250-1350. Oxford: Oxford University Press, 1989.

Anonym. Markaz Rubi Jubilee Souvenir. Kozhikode: Jamia Markazu Saqafathi Sunniyya, 2018. 
Appadurai, Arjun. Modernity at Large: Cultural Dimension of Globalization. Minneapolis: University of Minneapolis Press, 1996.

Arjomand, Saïd Amir. "Islam, Political Change and Globalization." Thesis Eleven 76, no. 1. TH11 40th Anniversary Collection (February 1, 2004): 9-28.

Asheem, P. K. "'Holy' Hair Brings Merger Talks Between Kerala Muslim Bodies to a Halt." News18. Last modified November 16, 2018. Accessed March 10, 2021. https://www.news18.com/news/india/holy-hair-bringsmerger-talks-between-kerala-muslim-bodies-to-a-halt1941137.html.

Atia, Mona. "'A Way to Paradise': Pious Neoliberalism, Islam, and Faith-Based Development." Annals of the Association of American Geographers 102, no. 4 (July 1, 2012): 808-827.

Bakar, Osman. "The Qur'anic Identity of the Muslim Ummah: Tawhidic Epistemology as Its Foundation and Sustainer." Islam and Civilisational Renewal (ICR) Journal 3, no. 3 (April 2012): 438-454.

Bowen, John R. "Beyond Migration: Islam as a Transnational Public Space." Journal of Ethnic and Migration Studies 30, no. 5 (September 1, 2004): 879-894.

Dar al-Ifta al Misriyyah. "The Concept of "The Ummah"." Dar AlIfta al Misriyyah. Accessed January 21, 2021. http://www.daralifta.org/Foreign/ViewArticle.aspx?ID=367\&CategoryID=3.

Decasa, G. C. The Quranic Concept of Ummah and Its Function in Philippine Muslim Society. Roma: Gregorian Biblical Book Shop, 1999.

Eisenstadt, S. N. "Post-Traditional Societies and the Continuity and Reconstruction of Tradition." Daedalus 102, no. 1 (1973): 127.

Fathah, M Abdul. "Terrorism, an Orphan of Reformist Islam: Reflections from Kerala Muslim Milieu." WordPress.com. Cafe Dissensus Everyday, May 11, 2018. Accessed November 23, 2021. https://cafedissensusblog.com/2018/05/11/terrorism-anorphan-of-reformist-islam-reflections-from-kerala-muslimmilieu/. 
Fazal, Tanweer. "Ummah, Qaum and Watan: Elite and Ordinary Constructions of Nationhood among Muslims of Contemporary India." CAS Working paper series, Jawaharlal Nehru University, New Delhi, 2014. https://www.jnu.ac.in/sites/default/files/u63/tanweerpaper.pdf.

Gökkır, Necmettin. "Political Language of Tafsir: Redefining of Ummah, A Religio-Communal Concept of the Quran: Past and Present." İstanbul Üniversitesi İlahiyat Fakültesi Dergisi 15 (January 1, 2007): 245-272.

Halim, Asyiqin Ab. "Ibn Khaldun's Theory of Asabiyyah and the Concept of Muslim Ummah." Journal of Al-Tamaddun 9, no. 1 (June 30, 2014): 1-12.

Hasan, Mubashar. "The Concept of Globalization and How This Has Impacted on Contemporary Muslim Understanding of Ummah." Journal of Globalization Studies 2, no. 2 (January 1, 2011): 145-159.

Hassan, Mona. Longing for the Lost Caliphate: A Transregional History. Princeton, NJ: Princeton University Press, 2016.

Ilias, M.H. “Narrating the History of Malabar's Omani Connection with Special Reference to the Life Histories of Cheraman Perumal and Saiyyid Fadl Moplah" Presented at the Malabar Arab Relations, Oman, 2011.

Iqtidar, Humeira. "Redefining 'tradition in Political Thought." European Journal of Political Theory 15, no. 4 (September 16, 2016): 424-444.

Islamic Publishing House, ed. Islamic Encyclopedia Malayalam. Kerala: Islamic Publishing House, 2005.

- - , ed. Kerala Muslim History Conference Proceedings. Kerala: Islamic Publishing House, 2015.

Kadiruzzaman, Sabila. Islam Without Borders: Transnationalism, Social Justice, and Refugee Assistance. Notre Dame: The Program on Law \& Human Development, University of Notre Dame, 2012.

Kerr, Malcolm H. Islamic Reform: The Political and Legal Theories of Muhammed Abduh and Rashid Rida. California: University of California Press, 1966. 
Kooria, Mahmood. "Cosmopolis of Law: Islamic Legal Ideas and Texts across the Indian Ocean and Eastern Mediterranean Worlds." Doctoral Dissertation, Leiden University, 2016. https://www.academia.edu/30069524/Dissertation_Intro_Cosm opolis_of_Law_Islamic_Legal_Ideas_and_Texts_across_the_In dian_Ocean_and_Eastern_Mediterranean_Worlds_.

Mandaville, Peter. "Globalization and the Politics of Religious Knowledge: Pluralizing Authority in the Muslim World." Theory, Culture \& Society 24, no. 2 (March 1, 2007): 101-115.

Menon, M Gangadhara. "Mappila Outbreaks of 19th Century Malabar (The Background of the Malabar Rebellion of 1921)." In Proceedings of the Indian History Congress, 33:483-493, 1971.

- - - . The Malabar Rebellion 1921-1922. Allahabad: Vohra Publishers \& Distributors, 1989.

Menon, Nandagopal R. "What Do Polemics Do? Religion, Citizenship, and Secularism in South Indian Islam." History of Religions 58, no. 2 (November 1, 2018): 128-164.

Moosa, Ebrahim. "The Debts and Burdens of Critical Islam." In Progressive Muslims: On Justice, Gender and Pluralism, edited by Omid Safi, 111-127. Oxford: Oneworld, 2003.

Osella, Caroline, and F. Osella. "Nuancing the Migrant Experience: Perspectives from Kerala, South India." In Transnational South Asians: The Making of a Neo-Diaspora, edited by S. Koshy and R. Radhakrishnan, 146-178. India: Oxford University Press, 2008. https://eprints.soas.ac.uk/5175/.

Osella, Caroline, and Filippo Osella. "Muslim Style in South India." Fashion Theory: The Journal of Dress Body \& Culture 11, no. 2-3 (June 1, 2007): 233-252.

Osella, Filippo, and Caroline Osella. "Muslim Entrepreneurs between India \&amp; the Gulf." ISIM Review 19, no. 1 (2007): $8-9$.

Prange, Sebastian R. Monsoon Islam: Trade and Faith on the Medieval Malabar Coast. Cambridge Oceanic Histories. Cambridge: Cambridge University Press, 2018.

al-Qari, Mulla 'Ali ibn Sultan Muhammad. Mirqat Al-Mafatih. Vol. 6. Islamic Library App., 1992.

Quṭb, Sayyīd. Fì Zilāl al-Qur'ān. Cairo, Egypt: Dār al-Shurūq, 1988. 
Randathani, Husain. Mappila Malabar. Calicut: Islamic Publishing Bureau, 2008.

al-Rāzī, Fakhr al-Dīn. Tafsìr al-Kabīr. Beirut: Dār al-Hayā al-Turath al-Azali, 1995.

al-Sayyid, Usama. al-Haqq al-Mubīn fì Raddi 'ala Man Talā'aba bi alDìn. Translated by Arafa Waleed. Abu Dhabi: Dār al-Faqīh, 2017.

Sedgwick, Mark. Muhammad Abduh. Oxford: Oneworld, 2009.

Sen, Ronjoy, and Robin Jeffrey. Being Muslim In South Asia: Diversity and Daily Life. Oxford: Oxford University Press, 2014.

Sikand, Y. Bastions of the Believers: Madrasas and Islamic Education in India. Delhi: Penguin, 2005.

al-Ṭabarī, Abū Ja'far Muhammad ibn Jarīr ibn Yazīd. Jāmi' al-Bayān fì Ta'wìl al-Qur'ān. Beirut: Dār al-Fikr, 2001.

Varier, Megha. "Voice Note by ISIS Terrorist Declares Peace School in Kerala Has Their Supporters." The News Minute. Last modified April 10, 2018. Accessed March 12, 2021. https://www.thenewsminute.com/article/voice-note-isisterrorist-declares-peace-school-kerala-has-their-supporters79345.

Visakh, M. S., R. Santhosh, and C. K. Mohammed Roshan. “Islamic Traditionalism in a Globalizing World: Sunni Muslim Identity in Kerala, South India." Modern Asian Studies 55, no. 6 (November 2021): 2046-2087.

Younis, Sherif. "How 'Abduh's Caftan Brought Forth Today's Islamic Ideologies." Fondazione Internazionale OASIS. Last modified July 31, 2015. Accessed January 23, 2021. http://www.oasiscenter.eu/en/how-abduhs-caftan-broughtforth-todays-islamic-ideologies. 